\title{
Association of testicular germ cell tumor with polymorphisms in estrogen receptor and steroid metabolism genes
}

\author{
Alberto Ferlin, Francesco Ganz, Manuel Pengo, Riccardo Selice, \\ Anna Chiara Frigo and Carlo Foresta
}

Section of Clinical Pathology and Centre for Male Gamete Cryopreservation, Department of Histology, Microbiology and Medical Biotechnologies, University of Padova, Via Gabelli 63, 35121 Padova, Italy

${ }^{1}$ Department of Environmental Medicine and Public Health, University of Padova, Via Loredan 18, 35131 Padova, Italy

(Correspondence should be addressed to C Foresta; Email: carlo.foresta@unipd.it)

\begin{abstract}
It is generally assumed that the development of testicular germ cell tumor (TGCT) is under endocrine control. In particular, unbalanced androgen/estrogen levels and/or activity are believed to represent the key events for TGCT development and progression. Furthermore, recent evidence has suggested a strong genetic component for TGCT. In this study, we analyzed whether a genetic variation in estrogen receptor (ESR) genes and steroid hormone metabolism genes is associated with TGCT. We genotyped for 17 polymorphic markers in 11 genes in 234 TGCT cases and 218 controls: ESR (ESR1 and ESR2); CYP19A1 (aromatase); 17 $\beta$-hydroxysteroid dehydrogenase types 1 and 4 (HSD17B1 and HSD17B4) dehydrogenases that convert potent androgens and estrogens to weak hormones; cytochrome $\mathrm{P} 450$ hydroxylating enzymes CYP1A1, CYP1A2, and CYP1B1; and the metabolic enzymes COMT, SULT1A1, and SULT1E1. We observed a significant association of rs11205 in HSD17B4 with TGCT. TGCT risk was increased twofold per copy of the minor $A$ allele at this locus (odds ratios $(O R)=2.273,95 \%$ confidence interval $(\mathrm{Cl})=1.737-2.973)$. Homozygous carriage of the minor A allele was associated with an over fourfold increased risk of TGCT $(\mathrm{OR}=4.561,95 \% \mathrm{Cl}=2.615-7.955)$ compared with homozygous carriage of the major $\mathrm{G}$ allele. The risk was increased both for seminoma $(\mathrm{OR}=5.327,95 \% \mathrm{Cl}=2.857-9.931)$ and for nonseminoma $(\mathrm{OR}=3.222,95 \%$ $\mathrm{Cl}=1.471-7.059)$. We found for the first time an association of polymorphisms in HSD17B4 gene with TGCT. Our findings expand the current knowledge on the role of genetic contribution in testicular cancer susceptibility, and support the hypothesis that variations in hormone metabolism genes might change the hormonal environment implicated in testicular carcinogenesis.
\end{abstract}

Endocrine-Related Cancer (2010) 17 17-25

\section{Introduction}

Testicular cancer (TC, MIM 273300) is the most common cancer in white males aged $20-40$ years, with a worldwide incidence of 7.5 per 100000 . About $95 \%$ of all TCs are represented by testicular germ cell tumors (TGCTs), and seminoma accounts for about $50 \%$ of them. Epidemiological hallmarks of TGCT include a peak incidence in a very young adult age, a markedly increasing incidence worldwide (Giwercman et al. 1993, Swerdlow et al. 1998) but with striking geographic and ethnic differences, and association with other reproductive conditions, such as cryptorchidism, testicular atrophy, and infertility (Horwich et al. 2006, Rajpert-De Meyts 2006).

A number of lines of evidence have pointed toward a strong hereditary component for TGCT. TGCT has high familial risks compared with most other cancer types: brothers of individuals with TGCT have an 8- to 12 -fold increased risk of disease, and fathers of affected individuals have a four- to six-fold increased risk (Swerdlow et al. 1997, Hemminki \& Li 2004). The proportion of TGCT susceptibility accounted for by the genetic effects is estimated at $25 \%$, and TGCT has the third highest heritability among all cancers 
(Czene et al. 2002). Early results from linkage studies identified a limited relationship with genetic factors (Crockford et al. 2006). A linkage on Xq27 was not replicated (Rapley et al. 2000), and the gr/gr deletion on the Y chromosome, which seems to increase TGCT risk two- to three-fold and is also associated with spermatogenic impairment, might account only for a limited number of cases because carriage frequency of this variant is low (2-3\%; Nathanson et al. 2005). However, two recent genome-wide association studies have reported associations at three new loci, including two candidate genes previously implicated in testicular development, KITLG (ligand for the receptor tyrosine kinase) and sprouty 4 (SPRY4), therefore supporting the contribution of a genetic predisposition to TGCT on firmer grounds (Kanetsky et al. 2009, Rapley et al. 2009).

Although a definitive proof is still lacking, it is generally assumed that the development of TGCT is under endocrine control and tumor-initiating events seem to occur early in life, probably during fetal development. In particular, alterations in the pituitary-testicular hormonal axis and/or alterations in gonadotropin and sex steroid action are believed to be involved in the development of this tumor and in the progression from the pre-invasive carcinoma in situ stage to invasive tumor (Rajpert-De Meyts 2006). Probably, a combination of high gonadotropin levels coupled with unbalanced androgen/estrogen levels and/or activity is the key event for TGCT development and progression (Garolla et al. 2005, Rajpert-De Meyts 2006). Supporting this hypothesis, recently an association of TC with maternal estrogen and androgen levels in early pregnancy has been reported (Holl et al. 2009). In addition, exposure to endocrine-disrupting chemicals acting as either weak estrogen agonist or androgen antagonist via binding to the estrogen and androgen receptors has been suggested to be associated with the risk of TGCT and other reproductive disorders (Wohlfahrt-Veje et al. 2009).

Exposure to exogenous and/or endogenous hormones could be modulated by genetic variation in hormone receptor and hormone metabolism genes. Recent evidence supports an association of TGCT with polymorphisms in these genes: we and others have reported an association with CAG/GGN repeat length of the androgen receptor gene (Giwercman et al. 2004, Garolla et al. 2005) and with FSH receptor gene polymorphisms (Ferlin et al. 2008a), and an association with some maternal and/or offspring hormonemetabolizing genes of the cytochrome P450 family (CYP1A1, CYP1A2, CYP3A4, and CYP3A5) has been suggested (Starr et al. 2005, Figueroa et al. 2008).

In this study, we sought to expand this knowledge to determine whether a genetic variation in estrogen receptor (ESR) genes and steroid hormone metabolism genes is associated with TGCT. Genotyping included 11 genes: ESR (ESR1 and ESR2); CYP19A1 (aromatase, which converts testosterone and androstenedione to estradiol and estrone respectively); $17 \beta$-hydroxysteroid dehydrogenase types 1 and 4 (HSD 17B1 and HSD17B4) dehydrogenases that convert androstenedione to testosterone and estrone to estradiol and vice versa; cytochrome P450 hydroxylating enzymes $C Y P 1 A 1, C Y P 1 A 2$, and $C Y P 1 B 1$ that metabolize estradiol and estrone to catechol metabolites; COMT that degrades the catechol metabolites to methylated compounds; and SULTIAI and SULTIE1 that degrade the catechol metabolites to sulfated compounds (Fig. 1).

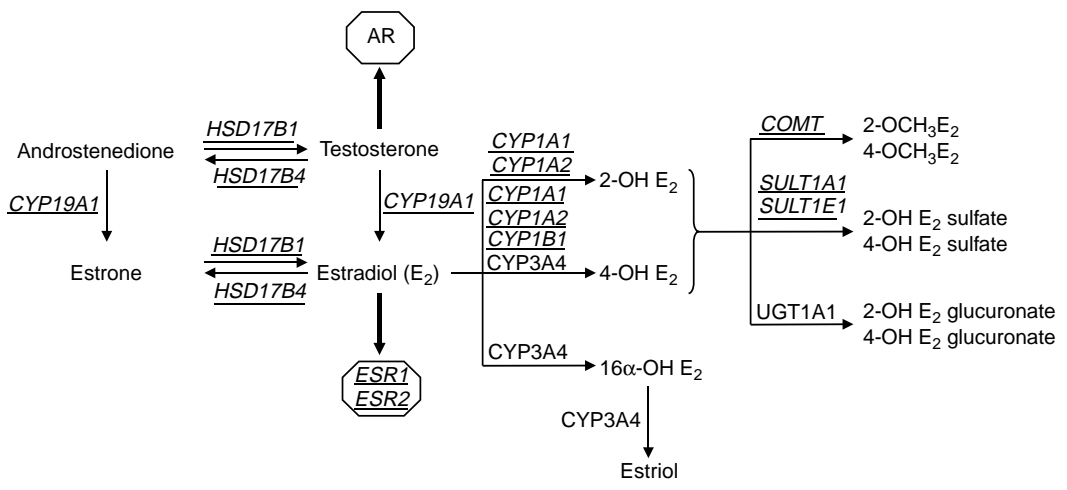

Figure 1 Metabolism of estrogens. The effect of P450 cytochrome enzymes (CYP) is shown together with the action of COMT that degrades the catechol metabolites to methylated compounds, SULT enzymes that degrade the catechol metabolites to sulfated compounds, and UGT enzymes that degrade the catechol metabolites to glucuronate compounds. Estrone is metabolized in the same way as estradiol. Genes included in the genotyping are underlined. ESR, estrogen receptor; AR, androgen receptor. 


\section{Materials and methods}

\section{Subjects and clinical analyses}

Patients and controls were prospectively recruited for this study from January 2005 to December 2008 with the approval of the Hospital Ethical Committee, and informed consent was obtained from each subject after full explanation of the purpose and nature of all the procedures used. The study has been conducted in accordance with the guidelines in the Declaration of Helsinki.

We evaluated 234 consecutive subjects (mean age $30.2 \pm 8.2$ years) orchiectomized for TGCT, who consulted our Center for semen cryobanking before initiating chemo- and/or radiotherapy. Totally, 173 men were affected by seminoma and 61 by nonseminoma ( 29 by embryonal carcinoma, 19 by teratoma, 8 by choriocarcinoma, and 5 by yolk sac tumor). Only those with a primary disease in the testis were included. A complete medical history, including the information on the familiarity for TGCT, type of TGCT, age at diagnosis, the presence of a history of cryptorchidism and laterality of disease, and physical examination, was undertaken. Karyotype analysis, Y chromosome microdeletion analysis (Ferlin et al. 2007a), and androgen receptor gene mutation analysis (Ferlin et al. 2006, 2008b) were performed in all the subjects to exclude the potential genetic causes of testicular damage, but no alterations were found among the 234 subjects. Male controls were represented by 218 disease-free men (mean age $37.3 \pm 11.8$ years) recruited among the blood donors representing the general population. More than $40 \%$ of the controls were older than 40 years and had already passed the peak of TGCT development. Prior to inclusion, all the controls underwent andrological examination including testicular ultrasound. All cases and controls were from the northeast of Italy.

Table 1 reports the main clinical characteristics of the cases and controls.

\section{Single nucleotide polymorphism selection}

After DNA isolation from peripheral leukocytes (QIAamp DNA blood kit, Qiagen), genotyping was performed with the GenomeLab SNPStream DNA genotyping platform (Beckman Coulter, Fullerton, CA, USA) and its accompanying SNPstream software suite after optimal design of the pairs of primers for the multiplex PCR and the single-base extension primers.

We studied 11 genes involved in steroid metabolism and the ESR. Single nucleotide polymorphisms (SNPs) were selected based on published evidence of
Table 1 Age, family history of testicular germ cell tumor (TGCT), history of cryptorchidism, and tumor type for cases and controls

\begin{tabular}{|c|c|c|c|c|}
\hline & \multicolumn{2}{|c|}{ Cases $(n=234)$} & \multicolumn{2}{|c|}{ Controls $(n=218)$} \\
\hline & No. & $\%$ & No. & $\%$ \\
\hline Age (mean \pm s.D.) & \multicolumn{2}{|c|}{$30.2 \pm 8.2$} & \multicolumn{2}{|c|}{$37.3 \pm 11.8$} \\
\hline \multicolumn{5}{|c|}{ Family history of TGCT } \\
\hline No & 221 & 94.4 & 208 & 95.4 \\
\hline Yes & 8 & 3.4 & 3 & 1.4 \\
\hline Unknown & 5 & 2.2 & 7 & 3.2 \\
\hline \multicolumn{5}{|c|}{ Personal history of cryptorchidism } \\
\hline No & 205 & 87.6 & 208 & 95.4 \\
\hline Yes & 23 & 9.8 & 2 & 0.9 \\
\hline Unknown & 6 & 2.6 & 8 & 3.7 \\
\hline \multicolumn{5}{|l|}{ Tumor type } \\
\hline Seminoma & 173 & 73.9 & - & - \\
\hline Nonseminoma & 61 & 26.1 & - & - \\
\hline
\end{tabular}

a correlation with functional activity, estradiol level, or estrogen-related outcomes (such as breast cancer). Furthermore, only SNPs with a minor allele frequency (MAF) $\geq 0.05$ (dbSNP, www.ncbi.nlm.nih.gov) were selected. Finally, we selected only A/G or C/T base substitutions to simplify the allele-specific tag extension reaction. At the end of this process, we selected 17 polymorphisms (Table 2). DNA sequences encompassing the SNP sites were analyzed by a Blast search (http://www.ncbi.nlm.nih.gov/BLAST/) to reveal highly homologous and repetitive elements. Then, a specific software (http://www.autoprimer.com, Beckman Coulter) was used for the design of the 17 pairs of primers (amplifying a short stretch of DNA of 90-150 bp that encompasses the SNP of interest) for the multiplex PCR and of the corresponding tagged extension primers.

\section{Genotyping}

Multiplex PCR was performed in an MJ thermal cycler (MJ Research, Waltham, MA, USA) under the following conditions: one denaturation cycle at $94{ }^{\circ} \mathrm{C}$ for $1 \mathrm{~min}$ and 40 cycles with denaturation at $94{ }^{\circ} \mathrm{C}$ for $1 \mathrm{~min}$, annealing at $55^{\circ} \mathrm{C}$ for $30 \mathrm{~s}$, and extension at $72{ }^{\circ} \mathrm{C}$ for $1 \mathrm{~min}$, followed by a final extension at $72{ }^{\circ} \mathrm{C}$ for $1 \mathrm{~min}$. The reaction was performed in a final volume of $25 \mu \mathrm{l}$ with $10 \mathrm{ng}$ genomic DNA, $75 \mu \mathrm{M}$ dNTP mix, $50 \mathrm{nM}$ primer pool, $5 \mathrm{mM} \mathrm{MgCl}_{2}$, and $0.5 \mathrm{U}$ Taq polymerase (Amplitaq Gold, Applera, Milano, Italy) in PCR $1 \times$ buffer. PCR products were purified by Exo-Sap reaction $(0.67 \mathrm{U}$ exonuclease $\mathrm{I}$ and $0.33 \mathrm{U}$ shrimp alkaline phosphatase in $3 \mu \mathrm{lmix}$ volume), which was performed in an Applied Biosystem thermal cycler to degrade the unincorporated PCR primers and dNTPs 
Table 2 Single nucleotide polymorphisms (SNPs) evaluated with the minor allele frequency

\begin{tabular}{|c|c|c|c|c|c|}
\hline Gene & Gene name & $\begin{array}{c}\text { Chromosomal } \\
\text { location }\end{array}$ & $\begin{array}{c}\text { Nucleotide } \\
\text { change }\end{array}$ & $\begin{array}{c}\text { dbSNP } \\
\text { ID }\end{array}$ & $\begin{array}{l}\text { Minor allele } \\
\text { frequency }\end{array}$ \\
\hline \multirow[t]{3}{*}{ ESR1 } & \multirow[t]{3}{*}{ Estrogen receptor 1} & \multirow[t]{3}{*}{$6 q 25.1$} & IVS1-397T>C & rs2234693 & 0.45 \\
\hline & & & Ex8+1264T $>C$ & rs3798577 & 0.44 \\
\hline & & & IVS1 $-351 A>G$ & rs9340799 & 0.36 \\
\hline \multirow[t]{2}{*}{ ESR2 } & \multirow[t]{2}{*}{ Estrogen receptor 2} & \multirow[t]{2}{*}{$14 q 23.2$} & IVS2 $-299 \mathrm{C}>\mathrm{T}$ & rs1256030 & 0.42 \\
\hline & & & $E \times 6+32 G>A$ & rs1256049 & 0.06 \\
\hline CYP1A1 & $\begin{array}{l}\text { Cytochrome } \mathrm{P} 450 \text {, family } 1 \text {, subfamily } \mathrm{A} \text {, } \\
\text { polypeptide } 1\end{array}$ & $15 q 24.1$ & $E x 7+131 A>G$ & rs1048943 & 0.04 \\
\hline CYP1A2 & $\begin{array}{l}\text { Cytochrome } \mathrm{P} 450 \text {, family } 1 \text {, subfamily } \mathrm{A} \text {, } \\
\text { polypeptide } 2\end{array}$ & $15 q 24.1$ & IVS $4+43 A>G$ & rs2472304 & 0.40 \\
\hline \multirow[t]{2}{*}{ CYP1B1 } & \multirow{2}{*}{$\begin{array}{l}\text { Cytochrome } \mathrm{P} 450 \text {, family } 1 \text {, subfamily } \mathrm{B} \text {, } \\
\text { polypeptide } 1\end{array}$} & \multirow[t]{2}{*}{$2 \mathrm{p} 21$} & $-4977 \mathrm{~A}>\mathrm{G}$ & rs162555 & 0.22 \\
\hline & & & $E \times 3+1564 G>A$ & rs2855658 & 0.39 \\
\hline CYP19A1 & $\begin{array}{l}\text { Cytochrome } \mathrm{P} 450 \text {, family } 19 \text {, subfamily } \mathrm{A} \text {, } \\
\text { polypeptide } 1 \text { (aromatase) }\end{array}$ & $15 q 21.1$ & $\mathrm{Ex} 8+47 \mathrm{C}>\mathrm{T}$ & rs700519 & 0.05 \\
\hline$H S D 17 B 1$ & Hydroxysteroid (17 $\beta)$ dehydrogenase 1 & $17 q 11-q 21$ & $E \times 6+220 G>A$ & rs605059 & - \\
\hline \multirow[t]{3}{*}{ HSD17B4 } & \multirow[t]{3}{*}{ Hydroxysteroid (17ß) dehydrogenase 4} & \multirow[t]{3}{*}{$5 q 23$} & $E \times 6+15 G>A$ & rs25640 & 0.46 \\
\hline & & & Ex19-6G $>A$ & rs11205 & 0.46 \\
\hline & & & $\mathrm{Ex} 24+61 \mathrm{~A}>\mathrm{G}$ & rs28943594 & 0.00 \\
\hline COMT & Catechol-O-methyltransferase & $22 q 11.21$ & $E \times 4-12 G>A$ & rs4680 & 0.43 \\
\hline SULT1A1 & $\begin{array}{l}\text { Sulfotransferase family } 1 \mathrm{~A} \text {, } \\
\text { phenol-preferring, member } 1\end{array}$ & $16 \mathrm{p} 12.1$ & Ex10-145C $>T$ & rs1042157 & - \\
\hline SULT1E1 & $\begin{array}{l}\text { Sulfotransferase family } 1 \mathrm{E} \text {, } \\
\text { estrogen-preferring, member } 1\end{array}$ & $4 q 13.1$ & $\mathrm{Ex} 1+50 \mathrm{G}>\mathrm{A}$ & rs3736599 & 0.08 \\
\hline
\end{tabular}

(USB Corp., Cleveland, OH, USA), following the recommended conditions.

Extension reaction was performed in a mix containing TAMRA- and Bodipy-fluorescein-labeled dideoxynucleotides (ddNTPs) and a pool of allelespecific tagged extension primers. The tagged extension primers were directed toward a specific location in each well (containing a $4 \times 4$ oligonucleotide array) of the 384 SNPware plate because of the presence of a tag at the $5^{\prime}$ terminus of the extension primer, which was complementary to the arrayed oligonucleotides. The $3^{\prime}$ terminus of the tagged extension primers was complementary to the sequence adjacent to the SNP site. The extension reaction permits the incorporation of the dye-labeled dideoxynucleotides at the $3^{\prime}$ terminus of the tagged extension primer. In each $4 \times 4$ array, three positive controls and one negative control were included to ensure accuracy in the genotype determination. The extension reaction was performed in an $\mathrm{MJ}$ thermal cycler under the following conditions: one denaturation cycle at $96^{\circ} \mathrm{C}$ for $3 \mathrm{~min}$ and 44 cycles with a first step at $94{ }^{\circ} \mathrm{C}$ for $20 \mathrm{~s}$ and a second step at $40^{\circ} \mathrm{C}$ for $11 \mathrm{~s}$, and a final hold at $4{ }^{\circ} \mathrm{C}$. The reaction was performed in a final volume of $15 \mu \mathrm{l}$ with $0.04 \mu \mathrm{l}$ SNP extension mix, $5.6 \mu \mathrm{l}$ SNPware extension dilution buffer, $0.3 \mu$ SNP $20 \times$ extension mix, and $0.03 \mu \mathrm{l}$ SNPware DNA polymerase (Beckman Coulter). The SNP $20 \times$ extension mix contains the dye-labeled dideoxynucleotides, which are used in the primer extension reaction, and selfannealing oligonucleotides that are extended with dye-labeled terminators, which serve as positive controls in each well.

The extension products were transferred to the SNPware plate so that each extended primer could hybridize in a specific way to one of the unique probes arrayed in each well. A $12 \mu \mathrm{l}$ volume of the hybridization mix (Beckman Coulter) was added to each well. The SNPware plate was incubated at $42{ }^{\circ} \mathrm{C}$ for $2 \mathrm{~h}( \pm 15 \mathrm{~min})$ in a humid chamber and was then washed thrice to remove the probes that were not arrayed.

The SNPware plate was analyzed with the GenomeLab SNPStream array imager that detects the fluorescent signal of the extended base for each spot. GetGenos software (Beckman Coulter, Fullerton, CA, USA) assigns the genotype to each SNP spot on the basis of the fluorescence intensity. Self-annealing oligonucleotides are used to get a correct grid alignment based on four fixed controls composed by oligonucleotides in homozygosis in blue and green and in heterozygosis and a blank control.

From the analysis, we obtained three possible calls for each spot in the 384 SNPware plate and these were collected into three clusters, one representing the homozygous $\mathrm{XX}$ genotype, one representing the 


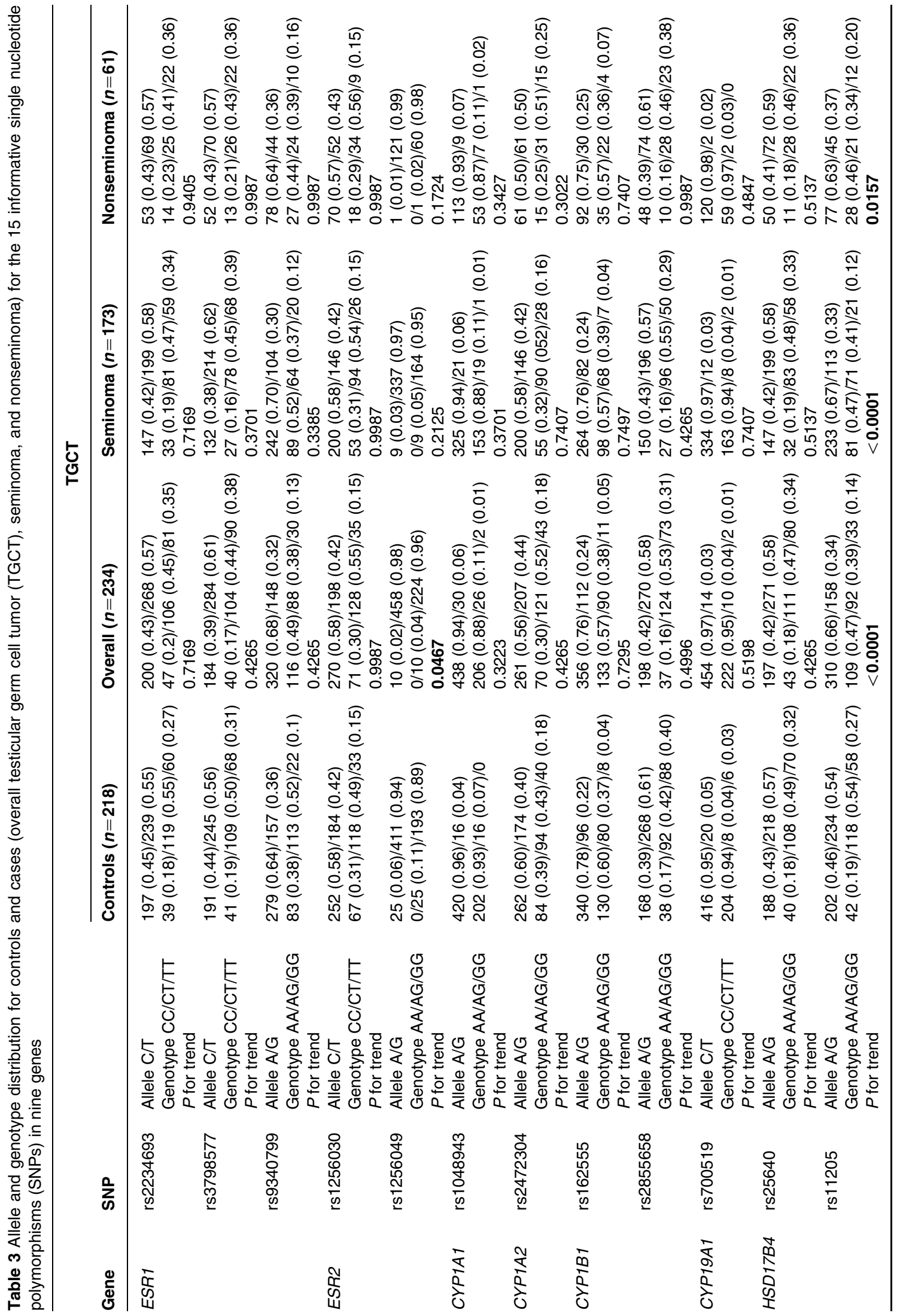




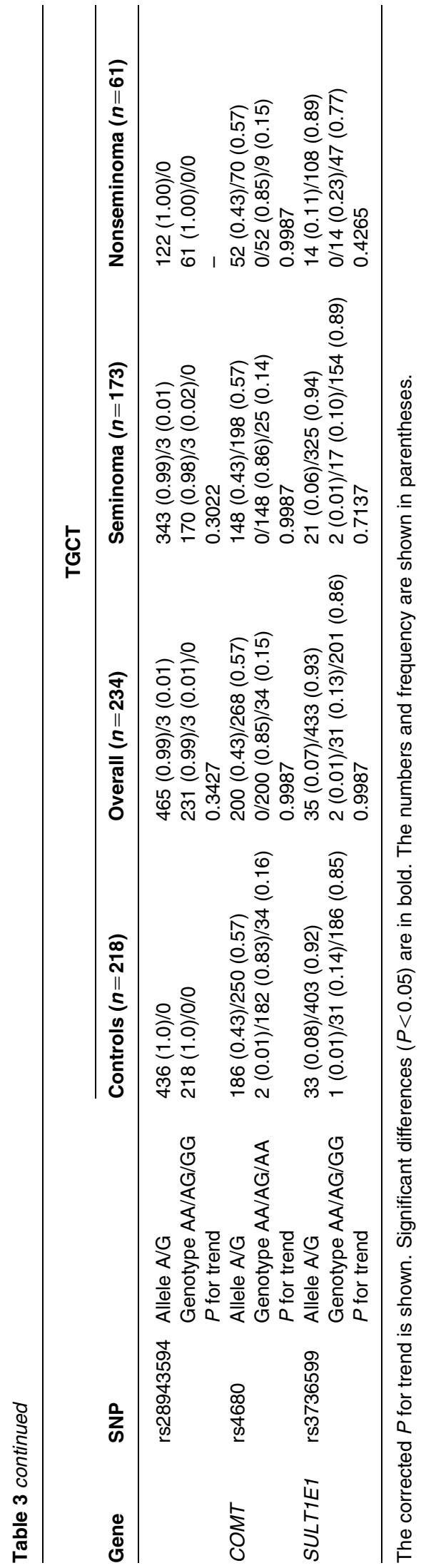

heterozygous $\mathrm{XY}$ genotype, and one representing the homozygous YY genotype. Plot data were finally converted into an Excel format by the software itself, registering the genotype observed for each SNP in the samples analyzed.

\section{Statistical analysis}

Tests for Hardy-Weinberg equilibrium (HWE) were performed for each SNP for controls and cases with the use of the $\chi^{2}$ Goodness-of-Fit test. The extent of linkage disequilibrium (LD) among SNPs was quantified using Lewontin's $D^{\prime}$ value and the correlation coefficient $r^{2}$. A pair of SNPs was defined as being in high LD if they had $D^{\prime}>0.8$ and $r^{2}>0.5$. Differences in allele and genotype distribution between cases and controls were tested with the use of Cochran-Armitage trend test. Odds ratios (OR) and $95 \%$ confidence interval (95\% CI) were estimated to assess the effect of each SNP on cancer risk using a logistic regression model. Allelic ORs and 95\% CIs were estimated on the basis of a multiplicative model. All reported $P$ values were corrected to account for multiple comparisons using the false discovery rate Benjamini-Hochberg method. Two-sided adjusted $P$ values are reported, and $P$ of $<0.05$ was considered to indicate statistical significance. Statistical analyses were conducted with SAS Version 9.1.1 (SAS Institute Inc., Cary, NC, USA).

\section{Results}

The genes and SNPs analyzed with minor allele frequencies among controls are shown in Table 2. Out of the 17 markers selected in 11 genes, 2 (rs605059 in $H S D 17 B 1$ and rs1042157 in SULT1A1) had high missing data rates, and were therefore not considered for further analysis. The other 15 SNPs were all in HWE equilibrium both in controls and cases, but 2 (rs1048943 in CYP1A1 and rs28943594 in HSD17B4) had a MAF $<0.05$. LD analysis showed no linkage between the markers of the same gene.

Table 3 shows the allele and genotype distribution in TGCT cases (overall, seminoma, and nonseminoma) and controls of the 15 informative markers of nine genes. We observed a significant association of rs11205 in HSD17B4 with TGCT, with a $P$ for trend $<0.0001$ for TGCT considered as a whole and for seminoma, and 0.0157 for nonseminoma. TGCT risk was increased twofold per copy of the minor A allele in HSD17B4 rs11205 (OR $=2.273,95 \%$ $\mathrm{CI}=1.737-2.973$; Table 4). Homozygous carriage of the minor A allele at this locus was associated with an over fourfold increased risk of TGCT $(\mathrm{OR}=4.561$, 
Table 4 Associations of testicular germ cell tumor (TGCT) with single nucleotide polymorphism (SNP) marker rs11205 in HSD17B4 gene (risk allele A)

\begin{tabular}{llllll}
\hline & \multicolumn{2}{c}{ Genotype count $^{\mathrm{a}}$} & & \multicolumn{2}{c}{ OR (95\% Cl) } \\
Tumor type & Controls & Cases & Per allele & Heterozygote & Homozygote $^{\text {c }}$ \\
\hline All TGCTs & $42 / 118 / 58$ & $109 / 92 / 33$ & $2.273(1.737-2.973)$ & $1.370(0.825-2.275)$ & $4.561(2.615-7.955)$ \\
Seminoma & $42 / 118 / 58$ & $81 / 71 / 21$ & $2.388(1.782-3.202)$ & $1.662(0.931-2.967)$ & $5.327(2.857-9.931)$ \\
Nonseminoma & $42 / 118 / 58$ & $28 / 21 / 12$ & $1.982(1.311-2.996)$ & $0.860(0.396-1.869)$ & $3.222(1.471-7.059)$ \\
\hline
\end{tabular}

${ }^{a}$ Number of individuals genotyped as homozygous for the risk allele/heterozygous for the risk allele/homozygous for the nonrisk allele.

${ }^{\mathrm{b}} \mathrm{OR}$ for heterozygous carriage of risk allele compared with that for homozygous carriage of nonrisk allele.

${ }^{\mathrm{c}} \mathrm{OR}$ for homozygous carriage of risk allele compared with that for homozygous carriage of nonrisk allele.

95\% CI $=2.615-7.955)$ compared with homozygous carriage of the major $\mathrm{G}$ allele (Table 4). The increased risk was higher for seminoma $(\mathrm{OR}=5.327,95 \% \mathrm{CI}=$ 2.857-9.931) than for nonseminoma $(\mathrm{OR}=3.222$, $95 \% \mathrm{CI}=1.471-7.059)$. Heterozygous carriage of the A/G allele did not increase the risk of TGCT.

A weak association was also found with rs1256049 in ESR2 only for TGCT considered as a whole ( $P$ for trend was 0.0467). However, no homozygotes for the minor A allele were found in cases and controls, and OR calculation showed no increased risk.

\section{Discussion}

This study analyzed the possible association between polymorphisms in ESR and estrogen metabolism genes and TGCT. By studying 17 SNPs in 11 genes, we found that one polymorphism in the HSD $17 B 4$ gene is associated with risk of TGCT. In particular, the TGCT risk was increased twofold per copy of the minor A allele in $H S D 17 B 4$ and more than fourfold for A homozygotes compared with homozygous carriage of the major $\mathrm{G}$ allele. The risk was increased for both types of TGCTs, but it was higher for seminoma $(\mathrm{OR}=5.327)$ than for nonseminoma $(\mathrm{OR}=3.222)$.

$H S D 17 B 4$ gene encodes for the HSD17B4, the enzyme that inactivates estradiol to estrone and converts testosterone to androstenedione. Although there is no functional information for the HSD17B4 SNP (rs11205) with which we found an association in the current study, some evidence suggests that it might alter the enzyme activity. The $\mathrm{G}>\mathrm{A}$ polymorphism of rs11205 is a missense mutation located in exon 19 that leads to amino acid change ( $\mathrm{Val}>\mathrm{Ile}$ ). Although these two amino acids have similar physico-chemical properties and are both medium sized and hydrophobic, this residue is highly conserved among the species and it is part of a conserved domain composing the substrate binding site. Therefore, change in functional activity of the $H S D 17 B 4$ enzyme could be hypothesized, leading to an alteration in the levels of sex hormones and therefore changing susceptibility to TGCT. Several lines of evidence support our findings and this hypothesis.

Unbalanced androgen/estrogen levels and/or activity are believed to represent the key events for TGCT development and progression (Garolla et al. 2005, Rajpert-De Meyts 2006). The frequent association of TGCT with other disorders of the male genital tract suggested the existence of a 'testicular dysgenesis syndrome' (TDS; Skakkebaek et al. 2001) caused by genetic and environmental factors altering gonadal development in utero leading to clinical manifestations at birth (cryptorchidism and hypospadias) or in adulthood (spermatogenic failure and TGCT). This hypothesis also includes a possible role for endogenous and exogenous hormones or hormone-like substances (endocrine disruptors) mainly acting as estrogens or anti-androgens. Although direct evidence in humans is lacking, numerous animal models support this notion (Sharpe 2003, Sharpe \& Skakkebaek 2008), and associations of TGCT with maternal estrogen and androgen levels in early pregnancy have been reported (Holl et al. 2009).

Previous studies on polymorphisms in ESR, androgen receptor, and estrogen metabolism genes have documented an association with TGCT and/or other signs of TDS, in particular cryptorchidism and male infertility (Ferlin et al. 2007b, Foresta et al. 2008, Krausz \& Looijenga 2008 for review). Associations with TGCT have been found with mutations in the androgen receptor gene (Garolla et al. 2005), different lengths of the CAG and GGC repeats in exon 1 of the androgen receptor gene which modulate the sensitivity of the receptor to androgens (Giwercman et al. 2004, Garolla et al. 2005), polymorphisms of the FSH receptor gene which modulate FSH sensitivity (Ferlin et al. 2008a), and polymorphisms in cytochrome P450 genes involved in estrogen metabolism (Starr et al. 2005, Figueroa et al. 2008). With regards to 
these latter genes, an association between TGCT and CYP1A2 (rs762551), CYP3A4 (rs2740574), and CYP3A5 (rs776746) gene polymorphisms was found by one study (Starr et al. 2005), whereas an association with polymorphisms in CYP1A1 (rs4886605 and rs2606345) gene was found by another one (Figueroa et al. 2008). We did not include CYP3A4 and CYP3A5 genes in our screening, nor we included SNPs rs4886605 and rs2606345 in CYP1Al and rs762551 in $C Y P 1 A 2$; therefore, we were unable to confirm such associations. On the contrary, Figueroa et al. (2008) also studied the HSD17B4 gene and they found no association with TGCT; however, SNP rs1 1205 that we found differently distributed between cases and controls was not included in their study. Taken together these results, although not definitive, strongly suggest that steroid hormone metabolism genes might modulate the susceptibility to TC. Supporting this idea, it is interesting to note that one polymorphism (rs2830) in the gene encoding for $H S D 17 B 1$, the enzyme that catalyzes the same reaction of $H S D 17 B 4$ converting weak estrogen estrone to potent estradiol, has been associated with nonseminoma risk (Figueroa et al. 2008). Interestingly, studies on breast cancer showed that other polymorphisms in this gene have been found to be associated with increased estrogen levels (Setiawan et al. 2004). Finally, the importance of variation in steroid hormone metabolism genes is also highlighted by the finding that polymorphisms in these genes, including HSDI7B4 that we found to be associated with TGCT, have been associated with the efficacy of the androgen-deprivation therapy in men with prostate cancer (Ross et al. 2008), a well-known hormone-dependent tumor.

Location of a disease-associated SNP in a gene does not necessarily implicate the gene in disease susceptibility. Therefore, an alternative hypothesis is that the association of SNP rs11205 in HSD17B4 with TGCT merely reflects functional alterations elsewhere near this SNP. However, this hypothesis is not supported by the two recent genome-wide association studies performed on a high number of TGCT cases (Kanetsky et al. 2009, Rapley et al. 2009), which found different chromosomal regions linked to the tumor but not in the vicinity of $H S D 17 B 4$ gene. In fact, a strong association was found for chromosome $5 \mathrm{q}$ (where HSD17B4 map) in both the studies, but the associated linkage block was about $23 \mathrm{Mb}$ far from rs11205 with which we found an association in the current study.

Although the sample size of our study is relatively large, the association between HSD17B4 gene polymorphisms and TGCT should be replicated in other studies with a larger number of patients and with additional polymorphisms in these loci. Therefore, our study although highly suggestive of a role for HSD17B4 gene polymorphisms in modulating the risk of TGCT should be considered as preliminary.

In conclusions, we found for the first time an association of polymorphisms in $H S D 17 B 4$ gene with TGCT. Our findings expand the current knowledge on the role of genetic contribution in TC susceptibility, and support the hypothesis that variations in hormone metabolism genes might change the hormonal environment implicated in testicular carcinogenesis.

\section{Declaration of interest}

The authors declare that there is no conflict of interest that could be perceived as prejudicing the impartiality of the research reported.

\section{Funding}

This work was supported in part by grants from the University of Padova (to A Ferlin) and the Italian Ministry of University and Research (grant number 2007TKYYJR) (to C Foresta).

\section{References}

Crockford GP, Linger R, Hockley S, Dudakia D, Johnson L, Huddart R, Tucker K, Friedlander M, Phillips KA, Hogg D et al. 2006 Genome-wide linkage screen for testicular germ cell tumour susceptibility loci. Human Molecular Genetics 15 443-451.

Czene K, Lichtenstein P \& Hemminki K 2002 Environmental and heritable causes of cancer among 9.6 million individuals in the Swedish Family-Cancer Database. International Journal of Cancer 99 260-266.

Ferlin A, Vinanzi C, Garolla A, Selice R, Zuccarello D, Cazzadore C \& Foresta C 2006 Male infertility and androgen receptor gene mutations: clinical features and identification of seven novel mutations. Clinical Endocrinology 65 606-610.

Ferlin A, Arredi B, Speltra E, Cazzadore C, Selice R, Garolla A \& Foresta C 2007a Molecular and clinical characterization of $\mathrm{Y}$ chromosome microdeletions in infertile men: ten years experience in Italy. Journal of Clinical Endocrinology and Metabolism 92 762-770.

Ferlin A, Raicu F, Gatta V, Zuccarello D, Palka G \& Foresta C $2007 b$ Male infertility: role of genetic background. Reproductive Biomedicine Online 14 734-745.

Ferlin A, Pengo M, Selice R, Salmaso L, Garolla A \& Foresta C 2008a Analysis of single nucleotide polymorphisms of FSH receptor gene suggests association with testicular cancer susceptibility. Endocrine-Related Cancer 15 429-437. 
Ferlin A, Zuccarello D, Zuccarello B, Chirico MR, Zanon GF \& Foresta C $2008 b$ Genetic alterations associated with cryptorchidism. Journal of the American Medical Association 300 2271-2276.

Figueroa JD, Sakoda LC, Graubard BI, Chanock S, Rubertone MV, Erickson RL \& McGlynn KA 2008 Genetic variation in hormone metabolizing genes and risk of testicular germ cell tumors. Cancer Causes \& Control 19 917-929.

Foresta C, Zuccarello D, Garolla A \& Ferlin A 2008 Role of hormones, genes, and environment in human cryptorchidism. Endocrine Reviews 29 560-580.

Garolla A, Ferlin A, Vinanzi C, Roverato A, Sotti G, Artibani W \& Foresta C 2005 Molecular analysis of the androgen receptor gene in testicular cancer. EndocrineRelated Cancer 12 645-655.

Giwercman A, Carlsen E, Keiding N \& Skakkebaek NE 1993 Evidence for increasing incidence of abnormalities of the human testis: a review. Environmental Health Perspectives 101 65-71.

Giwercman A, Lundin KB, Eberhard J, Stahl O, Cwikiel M, Cavallin-Stahl E \& Giwercman YL 2004 Linkage between androgen receptor gene $\mathrm{CAG}$ trinucleotide repeat length and testicular germ cell cancer histological type and clinical stage. European Journal of Cancer $\mathbf{4 0}$ 2152-2158.

Hemminki K \& Li X 2004 Familial risk in testicular cancer as a clue to a heritable and environmental aetiology. British Journal of Cancer 90 1765-1770.

Holl K, Lundin E, Surcel HM, Grankvist K, Koskela P, Dillner J, Hallmans G, Wadell G, Olafsdottir GH, Ogmundsdottir HM et al. 2009 Endogenous steroid hormone levels in early pregnancy and risk of testicular cancer in the offspring: a nested case-referent study. International Journal of Cancer 124 2923-2928.

Horwich A, Shipley J \& Huddart R 2006 Testicular germ-cell cancer. Lancet 367 754-765.

Kanetsky PA, Mitra N, Vardhanabhuti S, Li M, Vaughn DJ, Letrero R, Ciosek SL, Doody DR, Smith LM, Weaver J et al. 2009 Common variation in KITLG and at 5q31.3 predisposes to testicular germ cell cancer. Nature Genetics 41 811-815.

Krausz C \& Looijenga LH 2008 Genetic aspects of testicular germ cell tumors. Cell Cycle 7 3519-3524.

Nathanson KL, Kanetsky PA, Hawes R, Vaughn DJ, Letrero R, Tucker K, Friedlander M, Phillips KA, Hogg D, Jewett MA et al. 2005 The Y deletion gr/gr and susceptibility to testicular germ cell tumor. American Journal of Human Genetics 77 1034-1043.

Rajpert-De Meyts E 2006 Developmental model for the pathogenesis of testicular carcinoma in situ: genetic and environmental aspects. Human Reproduction Update 12 303-323.

Rapley EA, Crockford GP, Teare D, Biggs P, Seal S, Barfoot R, Edwards S, Hamoudi R, Heimdal K, Fossâ SD et al. 2000 Localization to Xq27 of a susceptibility gene for testicular germ-cell tumours. Nature Genetics $\mathbf{2 4}$ 197-200.

Rapley EA, Turnbull C, Al Olama AA, Dermitzakis ET, Linger R, Huddart RA, Renwick A, Hughes D, Hines S, Seal S et al. 2009 A genome-wide association study of testicular germ cell tumor. Nature Genetics $\mathbf{4 1}$ 807-810.

Ross RW, Oh WK, Xie W, Pomerantz M, Nakabayashi M, Sartor O, Taplin ME, Regan MM, Kantoff PW \& Freedman M 2008 Inherited variation in the androgen pathway is associated with the efficacy of androgendeprivation therapy in men with prostate cancer. Journal of Clinical Oncology 26 842-847.

Setiawan VW, Hankinson SE, Colditz GA, Hunter DJ \& De Vivo I 2004 HSD17B1 gene polymorphisms and risk of endometrial and breast cancer. Cancer Epidemiology, Biomarkers \& Prevention 13 213-219.

Sharpe RM 2003 The 'oestrogen hypothesis'- where do we stand now? International Journal of Andrology 26 2-15.

Sharpe RM \& Skakkebaek NE 2008 Testicular dysgenesis syndrome: mechanistic insights and potential new downstream effects. Fertility and Sterility 89 (Supplement 2) e33-e38.

Skakkebaek NE, Rajpert-De Meyts E \& Main KM 2001 Testicular dysgenesis syndrome: an increasingly common developmental disorder with environmental aspects. Human Reproduction 16 972-978.

Starr JR, Chen C, Doody DR, Hsu L, Ricks S, Weiss NS \& Schwartz SM 2005 Risk of testicular germ cell cancer in relation to variation in maternal and offspring cytochrome p450 genes involved in catechol estrogen metabolism. Cancer Epidemiology, Biomarkers \& Prevention 14 2183-2190.

Swerdlow AJ, De Stavola BL, Swanwick MA \& Maconochie NE 1997 Risks of breast and testicular cancers in young adult twins in England and Wales: evidence on prenatal and genetic aetiology. Lancet 350 1723-1728.

Swerdlow AJ, dos Santos Silva I, Reid A, Qiao Z, Brewster DH \& Arrundale J 1998 Trends in cancer incidence and mortality in Scotland: description and possible explanations. British Journal of Cancer 77 1-54.

Wohlfahrt-Veje C, Main KM \& Skakkebæk NE 2009 Testicular Dysgenesis syndrome; fetal origin of adult reproductive problems. Clinical Endocrinology $\mathbf{7 1}$ 459-465. 